
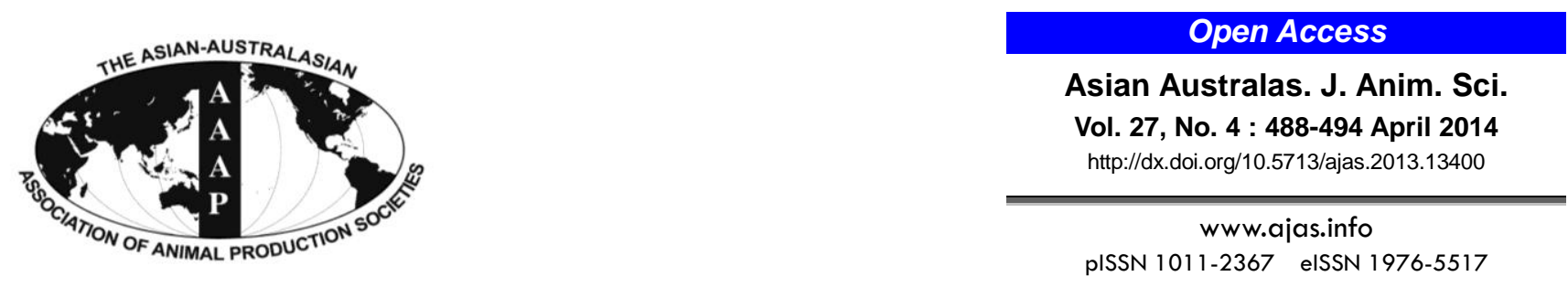

\title{
Effects of Copper and Selenium Supplementation on Performance and Lipid Metabolism in Confined Brangus Bulls
}

\author{
Arlindo Saran Netto ${ }^{1}$, , Marcus Antônio Zanetti ${ }^{1}$, Gustavo Ribeiro Del Claro ${ }^{1}$, \\ Mariza Pires de Melo ${ }^{2}$, Flávio Garcia Vilela ${ }^{3}$, and Lisia Bertonha Correa ${ }^{1}$ \\ College of Animal Science and Food Engineering, University of São Paulo, Pirassununga -SP, 13635-900, Brazil
}

\begin{abstract}
Twenty-eight Brangus cattle were used to determine the effect of copper and selenium supplementation on performance, feed efficiency, composition of fatty acids in Longissimus dorsi (LD) muscle, and cholesterol concentration in serum and in LD muscle and enzymes activities, reduced glutathione (GSH) and oxidized glutathione (GSSG). The treatments were: i) Control, without copper $(\mathrm{Cu})$ and selenium (Se) supplementation; ii) $\mathrm{Se}, 2 \mathrm{mg} \mathrm{Se} / \mathrm{kg}$ of dry matter such as sodium selenite; iii) $\mathrm{Cu}, 40 \mathrm{mg} \mathrm{Cu} / \mathrm{kg}$ of dry matter such as copper sulfate; iv) $\mathrm{Se} / \mathrm{Cu}, 2 \mathrm{mg} \mathrm{Se} / \mathrm{kg}$ of dry matter such as sodium selenite and $40 \mathrm{mg} \mathrm{Cu} / \mathrm{kg}$ of dry matter such as copper sulfate. LD muscle fatty acid composition was not influenced by the treatments ( $p>0.05)$. The serum concentration of cholesterol was not influenced by the treatments ( $>0.05)$, however, the concentration of cholesterol in LD was lower in cattle supplemented with copper and selenium $(\mathrm{p}<0.05)$. Oxidized glutathione and reduced glutathione increased $(\mathrm{p}<0.05)$ with $\mathrm{Cu}$, Se and Se/Cu supplementation. The supplementation of copper $(40 \mathrm{mg} / \mathrm{kg} \mathrm{DM})$ and selenium $(2 \mathrm{mg} / \mathrm{kg} \mathrm{DM})$ altered the metabolism of lipids in confined Brangus cattle, through a decrease in cholesterol deposition in the LD, possibly by changing the ratio between reduced glutathione/oxidized glutathione. Copper and selenium supplementation improved animal performance and feed efficiency $(\mathrm{p}<0.05)$ when compared to the control group, providing advantages in the production system, while also benefiting consumers by reducing cholesterol concentration in the meat. (Key Words: Cattle, Cholesterol, Fatty Acids, Minerals, Nutrition)
\end{abstract}

\section{INTRODUCTION}

Currently, much of the world population is seeking healthier food, thus producers and the feed industry are working to improve the quality of the final product. Cattle meat, which is rich in several nutrients, is frequently related to cardiovascular disease due to the high proportion of

\footnotetext{
* Corresponding Author: Arlindo Saran Netto. Tel: +55-1935654039, Fax: +55-19-35654047, E-mail: saranetto@usp.br

${ }^{1}$ Department of Animal Science, College of Animal Science and Food Engineering, University of São Paulo, Pirassununga-SP, Brazil.

${ }^{2}$ Department of Basic Science, College of Animal Science and Food Engineering, University of São Paulo, Pirassununga-SP, Brazil.

${ }^{3}$ Department of Nutrition and Animal Production, School of Veterinary Medicine and Animal Science, University of São Paulo, Pirassununga-SP, Brazil.

Submitted Jul. 5, 2013; Accepted Sept. 17, 2013; Revised Oct. 11, 2013
}

saturated fatty acids and cholesterol in the meat. Correa et al. (2012) observed that nutrition has an effect on feedlot performance and meat quality for the consumer. Boila (1987) related that in addition to the benefits for meat quality, supplementation with trace elements including copper and selenium, was responsible for weight gain by improving animal health, due to the direct effect on cellular metabolism and many enzymatic reactions.

Studies with animals and humans have shown that copper is involved with a great number of enzymatic reactions (Holben, 1999). Copper is an essential component of important metaloenzymes, such as cytochrome oxidase, superoxide dismutase, hydrolase and tyrosinase. Copper is vital during growth for defense mechanisms, iron transportation, cholesterol and glucose metabolism and brain development, among other functions (Felltman, 1991) In addition, it is necessary for the improved function of the immune system, cellular breath, bone formation, normal cardiac function, conjunctive tissue development, 
myelinization of spinal marrow, keratinization and pigmentation of tissues. Engle et al. (2000) showed that copper deficiency affects lipid metabolism, resulting in high levels of triglycerides, phospholipids and cholesterol in rat serum.

According to Engle and Spears (2001), copper deficiency causes an increase in plasma cholesterol. In rats, the deficiency revealed an increase in enzyme activity in the liver. Pesti and Bakalli (1996) found the addition of 125 or $250 \mathrm{mg}$ of $\mathrm{Cu}$ per $\mathrm{kg}$ of dry matter reduces plasma cholesterol and cholesterol in the chest muscle in chickens. Skrivan et al. (2002) supplementing chicken with 0, 13, 35, or $126 \mathrm{mg}$ of copper/kg of dry matter, with copper sulfate, noticed that there was a reduction of lipids and cholesterol in the muscle. Balevi and Coskum (2004); in an experiment carried out on hens, stated that copper supplementation reduced cholesterol concentration of in the yolk, without affecting bird performance.

Some experiments have suggested copper supplementation can affect lipid metabolism in ruminants (Engle and Spears, 2000; Engle et al., 2000a,b,c; Engle and Spears, 2001). The mechanism in which copper affects the profile of fatty acids is not clear, but it includes effects on bihydrogenation, esterification and mobilization of triglycerides. Copper has a high potential for reduction, and in rumen it can act on reduction reactions such as NADPH and $\mathrm{NADH}$, interfering in the microbial biohydrogenation of unsaturated fatty acids. Copper can reduce cholesterol synthesis in the small intestine, resulting in a decrease in serum and muscular cholesterol (Engle et al., 2000a).

Engle and Spears (2004), with the objective of evaluating the effects of copper supplementation in Angus bulls on muscle lipid composition, concluded that the supplemented steers had lower reduced glutathione (GSH) and higher concentration of the oxidized form (GSSG). The decrease in intracellular GSH occurs through the protection of hepatic cells from toxic effects of free radicals, from high copper concentration. Copper entering liver cells was quickly transferred to metallothionein (Freedman cited by Engle et al., 2000b). The increased concentration of the oxidized form (GSSG) has shown an indirect relationship with enzyme HMG-CoA activity (Engle and Spers, 2001).

Selenium is a semi-metal that can exist in several oxidation conditions. McDowel (1992) discovered the selenium function in animal nutrition when the author observed that selenium supplementation avoided liver necrosis in rats. After this finding, the prevention of muscular dystrophy was reported when bovine and sheep were supplemented with selenium. In the animal organism, selenium is incorporated to several enzymes, and the most important is glutathione peroxidase. Glutathione peroxidase (GPX) and glutathione reductase enzyme action is related to glutathione reduction and oxidation (Bakalli et al., 1995).

The hypothesis is that high supplementation with copper indirectly regulates cholesterol biosynthesis by decreasing reduced form glutathione (GSH) and increasing of the oxidized form (GSSG). Selenium could also influence cholesterol metabolism, since the peroxidase glutathione enzyme (GPX) is selenium dependent and the reductase glutathione enzyme acts on the GSH/GSSG ratio. Cattle feedlot with high concentrate to increase fat deposition and thus improve meat tenderness may have also increased the concentration of cholesterol in the meat, which is not beneficial to human health.

Therefore, the aim of the study was to evaluate the effect of supplementation with copper and selenium on the diet of Brangus cattle receiving high concentrate in performance parameters, feed efficiency, glutathione activity, fatty acid profile and cholesterol concentration in meat.

\section{MATERIALS AND METHODS}

\section{Animals and diets}

The experiment was performed at the College of Animal Science, University of São Paulo, Pirassununga-SP, for 131 days, 30 days for feedlot adaptation and 101 days for the experimental period. The animals utilized in this experiment were cared for by acceptable practices as summarized in the Guide for the Care and Use of Agricultural Animals Research and Teaching (FASS, 1999), and the protocol was reviewed and approved by the University of São Paulo, College of Animal Science and Food Engineering (USP/FZEA), Ethics Committee for the Use of Animals in Experiments.

Twenty-eight Brangus bulls were used, weighing $395 \pm 15 \mathrm{~kg}$ at the beginning of the experiment. They were individually fed a high concentrate diet $(75 \%)$, and corn silage $(25 \%)$ as roughage. The Cornell Net Carbohydrate and Protein System-CNCPS was used to verify the nutritional balance of the animals. The composition of the basal diet is presented in Table 1 .

The fatty acid (FA) profile in the diet was calculated in (g/100 g of FA): C18:0 3.298; C18:1 cis 9 10.835; C18:2 28.435; C18:3 1.283. The water was analyzed and it revealed the following mineral composition $(\mathrm{mg} / \mathrm{L}): \mathrm{Ca}$ 10.76; $\mathrm{Cu} 0.14 ; \mathrm{Fe}<0.02 ; \mathrm{P}<0.01 ; \mathrm{Mn}<0.003$; Total $\mathrm{N}<0.1$; $\mathrm{K} 1.75$; Na 2.85; Zn 0.105.

The twenty-eight bulls were divided in 4 groups, with 7 animals per treatment, and housed in individual pens. Treatments were: Treatment 1 , basal diet without additional copper and selenium supplementation; Treatment 2, basal diet with $2 \mathrm{mg}$ of selenium $/ \mathrm{kg}$ of dry matter, such as sodium selenite; Treatment 3, basal diet with supplementation of 40 $\mathrm{mg}$ of copper $/ \mathrm{kg}$ of dry matter, as copper sulphate; Treatment 4, basal diet with $40 \mathrm{mg} / \mathrm{kg}$ of copper supplementation, such as copper sulfate and $2 \mathrm{mg} / \mathrm{kg}$ of selenium, such as sodium selenite. During the experimental 
Table 1. Composition of the basal diet (dry matter)

\begin{tabular}{|c|c|}
\hline Ingredients and nutrients & $(\mathrm{g} / 100 \mathrm{~g})$ \\
\hline Corn silage & 25.000 \\
\hline Ground corn & 64.200 \\
\hline Extruded soybean & 7.875 \\
\hline Urea & 0.967 \\
\hline Sodium bicarbonate & 0.300 \\
\hline Salt & 0.285 \\
\hline Limestone & 0.600 \\
\hline Rumensin & 0.022 \\
\hline Mineral* & 0.750 \\
\hline \multicolumn{2}{|l|}{ Nutrients by analysis } \\
\hline Crude protein $(\%)$ & 12.90 \\
\hline Ether extract (\%) & 4.21 \\
\hline $\operatorname{NDF}(\%)$ & 18.34 \\
\hline $\mathrm{ADF}(\%)$ & 16.05 \\
\hline Copper $^{\mathrm{a}}(\mathrm{mg} / \mathrm{kg})$ & 5.80 \\
\hline Selenium $^{\mathrm{b}}(\mathrm{mg} / \mathrm{kg})$ & 0.06 \\
\hline \multicolumn{2}{|c|}{ 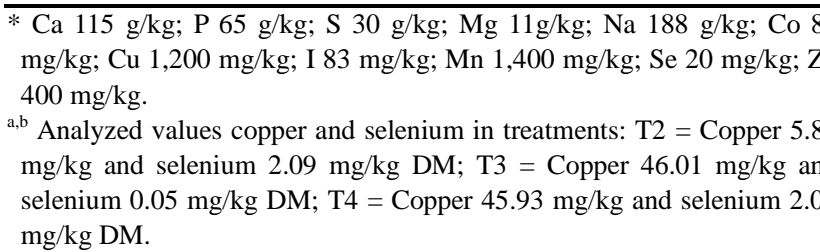 } \\
\hline
\end{tabular}

period, the animals were kept in individual pens with water available, and they were fed twice a day. The feed intake was measured daily. They were weighed at 28-day intervals, after a complete fast period of $18 \mathrm{~h}$.

\section{Sample collection}

Blood samples were collected from each steer before morning feeding via jugular venipureture into heparinized vacutainer tubes on $28,56,84$ days of experiment, then centrifuged at $1,100 \times \mathrm{g}$ for $10 \mathrm{~min}$ at $4^{\circ} \mathrm{C}$ to obtain plasma. After 84 days of the experimental diets in confinement, the animals were slaughtered, with food restricted for $16 \mathrm{~h}$, but water available, at the School Slaughterhouse of Pirassununga University Campus, according to routine procedure. Tissue samples were taken immediately after slaughter and frozen in liquid nitrogen. For determining the fatty acid profile and cholesterol, 4 samples of Longissimus dorsi (LD) muscle were collected, around $2.5 \mathrm{~cm}$ wide each. During the slaughter, samples of the right liver lobe were obtained from each animal and stored in liquid nitrogen for analysis of oxidized glutathione (GSSG), reduced glutathione (GSH) and glutathione peroxidase (GPX).

\section{Analytical procedures}

The determination of dry matter, mineral matter, crude protein, ether extract, acid detergent fiber of the diets followed AOAC (1996, Methods 930.15; 942.05; 988.05; 954.02; 973.18) recommendations. Selenium was determined using the fluorimetric method as described by
Olson et al. (1975) and copper levels using atomic absorption spectrophotometry (Perkin Elmer equipment).

The cholesterol analyses in muscle were performed using the enzymatic method according to Saldanha et al. (2004). The composition of fatty acids in LD muscle was performed using high resolution gas chromatography with the ThermoFinnigan chromatograph, model Trace with a flame ionization detector (FID) using a fused silica capillary column $100 \mathrm{~m}$ long, $0.25 \mathrm{~mm}$ in diameter and $0.2 \mathrm{~mm}$ thick. The carrier gas was helium with a flow rate set at 1.2 $\mathrm{mL} / \mathrm{min}$. One $\mathrm{mL}$ of sample was injected in split mode with a split ratio of $1 / 21$ at a temperature of $250^{\circ} \mathrm{C}$. Oven temperature was programmed to start at $70^{\circ} \mathrm{C}$ and remained so for $4 \mathrm{~min}$, raised to $170^{\circ} \mathrm{C}$ at $13^{\circ} \mathrm{C} / \mathrm{min}$ and finally to $250^{\circ} \mathrm{C}$ at $35^{\circ} \mathrm{C} / \mathrm{min}$ for $5 \mathrm{~min}$. The detector temperature was $300^{\circ} \mathrm{C}$ and the gas flow was 450,40 and $45 \mathrm{~mL} / \mathrm{min}$ for synthetic air, hydrogen and nitrogen (makeup), respectively, according to the methodology described by Perez et al. (2002)

Sodium phosphate buffer (10 mmol/L, $\mathrm{pH} 7.4)$ was used to extract the glutathione peroxidase (GPX) in liver. The liver samples were ground in a high speed potter homogenizer for $2 \mathrm{~min}$ at a ratio of one gram to $10 \mathrm{~mL}$ of cold extraction buffer $\left(4^{\circ} \mathrm{C}\right)$. After homogenization, samples were centrifuged at $8,000 \mathrm{rpm}$ for $10 \mathrm{~min}$ under refrigeration. The supernatant was removed carefully with a Paster pipette, transferred to a tube on ice and used to determine maximum enzyme activity.

Maximum glutathione peroxidase (GPX) activity was determined using the spectrophotometric method based on a decline in the concentration of NADPH at $340 \mathrm{~nm}$. To determine the GSH/GSSG ratio, samples of liver homogenate were precipitated in sulphosalicylic acid $5 \%$. Total glutathione was measured using the spectrophotometric method of recycling in the presence of nitrobenzoic acid, NADPH and reductase glutathione, to $412 \mathrm{~nm}$. GSSG was determined by direct derivation of GSH, by homogenizing another sample of the same tissue in the presence of $12.5 \mathrm{nM}$ N-ethylmaleimide, followed by alkaline hydrolysis.

The statistical design was completely randomized, with 7 replications per treatment (pen as experimental unit). The data were analyzed using SAS (SAS Institute Inc., Cary, NC, 2004), with contrasts, by PROC GLM. Serum cholesterol was analyzed using PROC MIXED. A 5\% significance level was adopted for all analyzed data.

\section{RESULTS AND DISCUSION}

\section{Daily gain and feed efficiency}

There was a significant difference in mineral supplementation in feed efficiency and daily weight gain (Table 2). 
Table 2. Feed intake (kg DM), feed efficiency (weight gain/dry matter intake), average daily weight gain and standard deviations of cattle receiving the control diet, supplemented with selenium, copper or selenium/copper

\begin{tabular}{|c|c|c|c|c|c|c|c|c|c|c|}
\hline & & Tre: & nents & & & & Cor & asts & & \\
\hline & $\mathrm{C}$ & $\mathrm{Se}$ & $\mathrm{Cu}$ & $\mathrm{Se} / \mathrm{Cu}$ & A & B & $\mathrm{C}$ & $\mathrm{D}$ & $\mathrm{E}$ & $\mathrm{F}$ \\
\hline Feed intake $(\mathrm{kg})$ & $10.91^{\mathrm{b}} \pm 2.32$ & $11.27^{\mathrm{a}} \pm 1.98$ & $11.05^{\mathrm{a}} \pm 2.54$ & $11.78^{\mathrm{a}} \pm 1.88$ & 0.03 & 0.04 & 0.02 & 0.10 & 0.11 & 0.92 \\
\hline Feed efficiency & $0.09^{c} \pm 0.01$ & $0.12^{\mathrm{a}} \pm 0.01$ & $0.11^{\mathrm{ab}} \pm 0.01$ & $0.10^{\mathrm{b}} \pm 0.01$ & $<0.01$ & 0.03 & 0.05 & 0.10 & 0.05 & 0.78 \\
\hline Daily weight gain (kg) & $0.98^{\mathrm{b}} \pm 0.24$ & $1.35^{\mathrm{a}} \pm 0.14$ & $1.21^{\mathrm{ab}} \pm 0.17$ & $1.18^{\mathrm{ab}} \pm 0.24$ & 0.01 & 0.06 & 0.09 & 0.26 & 0.17 & 0.84 \\
\hline
\end{tabular}

Cheng et al. (2008) reported no effect with 10 or $20 \mathrm{mg}$ $\mathrm{Cu} / \mathrm{kg} \mathrm{DM}$ in lambs, in the parameters of weight gain and feed efficiency. A similar result was found by Engle and Spears (2000a) working with steers and supplementing 10 or $40 \mathrm{mg} \mathrm{Cu} / \mathrm{kg}$ DM. However, as in our study, Zhang et al. (2007) verified the effect on weight gain and feed efficiency when adding $10 \mathrm{mg} \mathrm{Cu} / \mathrm{kg} \mathrm{DM}$ in the basal diet containing $7.38 \mathrm{mg} \mathrm{Cu} / \mathrm{kg} \mathrm{DM}$ in Inner Mongolian White Cashmere goats.

Lawler et al. (2004) supplemented steers with different sources of selenium at doses above the recommended by the NRC and reported no change in weight gain or feed efficiency. Engle and Spers (2000) reported that copper supplementation increased feed efficiency of cattle during the finishing period, compared to control treatment, the same results were obtained in this experiment. Copper and selenium play important roles in many enzymatic reactions and improve the immune response. We believe that these positive effects on animal metabolism may have contributed to better feed efficiency and animal performance.
The reason for the improved performance found in animals supplemented with selenium, copper and selenium/ copper in our study can be attributed to the intake of these minerals below the dosage recommended by NRC (2000) in the control treatment, since a negative control group was used without the inclusion of any of the minerals tested in this study. The basal diet used in the control treatment contained about $60 \%$ of the amount recommended by the NRC (2000), selenium and copper. Even though there were no clinical signs of copper and selenium deficiency in the control group, animals had an inferior performance when compared to supplemented animals during the experimental period, showing the importance of supplementation with those two minerals.

\section{Composition of fatty acids in muscle}

There was no significant difference in the proportion of saturated and unsaturated acids with copper, selenium and selenium/copper supplementation (Table 3). The results showed that copper, selenium and selenium/copper

Table 3. Profile of fatty acids in Longissimus dorsi muscle of cattle receiving control diet, selenium ( $2 \mathrm{mg} / \mathrm{kg}$ of DM), copper (40 mg/kg of DM) and selenium ( $2 \mathrm{mg} / \mathrm{kg}$ of DM)/copper (40 mg/kg of DM)

\begin{tabular}{|c|c|c|c|c|c|c|c|c|c|c|}
\hline \multirow{2}{*}{ Item } & \multicolumn{4}{|c|}{ Treatments } & \multicolumn{6}{|c|}{ Contrasts } \\
\hline & Control $^{\mathrm{a}}$ & Selenium $^{\mathrm{b}}$ & Copper $^{\mathrm{c}}$ & $\mathrm{Se} / \mathrm{Cu}^{\mathrm{d}}$ & $\mathrm{A}^{\mathrm{e}}$ & $\mathrm{B}^{\mathrm{f}}$ & $\mathrm{C}^{\mathrm{g}}$ & $\mathrm{D}^{\mathrm{h}}$ & $E^{i}$ & $\mathrm{~F}^{\mathrm{j}}$ \\
\hline & ---------------- & --------- g/1 & g de FA ----- & ---------------- & & & & & & \\
\hline Lauric & $10.48 \pm 3.04$ & $13.47 \pm 4.59$ & $13.64 \pm 5.35$ & $12.61 \pm 5.41$ & 0.25 & 0.23 & 0.41 & 0.94 & 0.75 & 0.70 \\
\hline $\mathrm{EPA}^{\mathrm{k}}$ & $0.16 \pm 0.43$ & $0.25 \pm 0.63$ & $0.31 \pm 0.77$ & $0.58 \pm 0.69$ & 0.79 & 0.67 & 0.24 & 0.87 & 0.38 & 0.46 \\
\hline Linolenic & $7.39 \pm 6.36$ & $7.71 \pm 7.07$ & $6.79 \pm 3.55$ & $8.32 \pm 5.68$ & 0.92 & 0.85 & 0.77 & 0.65 & 0.85 & 0.65 \\
\hline $\mathrm{DHA}^{1}$ & $1.23 \pm 1.25$ & $0.87 \pm 1.44$ & $0.66 \pm 0.87$ & $0.85 \pm 2.10$ & 0.66 & 0.49 & 0.64 & 0.80 & 0.90 & 0.81 \\
\hline Miristic & $1.69 \pm 0.72$ & $1.42 \pm 0.48$ & $1.39 \pm 0.68$ & $1.38 \pm 0.70$ & 0.47 & 0.43 & 0.39 & 0.94 & 0.89 & 0.88 \\
\hline Palmitoleic & $6.68 \pm 1.38$ & $6.25 \pm 1.51$ & $6.10 \pm 1.45$ & $6.53 \pm 2.37$ & 0.66 & 0.55 & 0.88 & 0.87 & 0.75 & 0.66 \\
\hline Linoleic & $10.31^{\mathrm{a}} \pm 3.35$ & $8.58^{\mathrm{ab}} \pm 2.10$ & $8.48^{\mathrm{ab}} \pm 2.59$ & $6.80^{\mathrm{b}} \pm 1.97$ & 0.24 & 0.22 & 0.02 & 0.95 & 0.25 & 0.27 \\
\hline Palmitic & $8.83^{\mathrm{a}} \pm 2.61$ & $6.74^{\mathrm{ab}} \pm 1.93$ & $7.00^{\mathrm{ab}} \pm 2.88$ & $6.05^{\mathrm{b}} \pm 2.41$ & 0.14 & 0.20 & 0.05 & 0.85 & 0.64 & 0.51 \\
\hline Oleic & $34.47 \pm 3.14$ & $32.75 \pm 2.20$ & $36.56 \pm 7.96$ & $37.30 \pm 3.40$ & 0.51 & 0.43 & 0.29 & 0.17 & 0.10 & 0.78 \\
\hline Estearic & $18.71 \pm 7.88$ & $21.94 \pm 6.20$ & $19.02 \pm 5.37$ & $19.54 \pm 5.25$ & 0.92 & 0.37 & 0.81 & 0.43 & 0.52 & 0.88 \\
\hline Saturated & $39.72 \pm 7.88$ & $43.57 \pm 6.03$ & $41.07 \pm 7.46$ & $39.59 \pm 9.09$ & 0.37 & 0.75 & 0.97 & 0.58 & 0.38 & 0.97 \\
\hline Unsaturated & $60.27 \pm 7.88$ & $56.42 \pm 6.03$ & $58.92 \pm 7.46$ & $60.41 \pm 9.09$ & 0.37 & 0.75 & 0.97 & 0.58 & 0.38 & 0.97 \\
\hline
\end{tabular}

${ }^{a}$ Control diet (without supplementation of copper and selenium).

${ }^{\mathrm{b}}$ Suplementation of selenium ( $2 \mathrm{mg} / \mathrm{kg}$ of DM). ${ }^{\mathrm{c}}$ Suplementation of copper (40 mg/kg of DM).

${ }^{\mathrm{d}}$ Suplementation of selenium $\left(2 \mathrm{mg} / \mathrm{kg}\right.$ of DM) and copper $\left(40 \mathrm{mg} / \mathrm{kg}\right.$ of DM). ${ }^{\mathrm{e}}$ Control X Se.

${ }^{\mathrm{f}}$ Control X Cu. ${ }^{\mathrm{g}}$ Control X Se/Cu. ${ }^{\mathrm{h}} \mathrm{Se} \mathrm{X} \mathrm{Cu} .{ }^{\mathrm{i}} \mathrm{Se} \mathrm{X} \mathrm{Se} / \mathrm{Cu} .{ }^{\mathrm{j}} \mathrm{Cu} \mathrm{X} \mathrm{Se/Cu} .{ }^{\mathrm{k}}$ Eicosapentaenoic acid. ${ }^{\mathrm{l}}$ Docosahexaenoic acid.

Means followed by different letters in rows differ $(\mathrm{p}<0.05)$. 
Table 4. Concentration of cholesterol and standard deviations in $\mathrm{mg} / \mathrm{dL}$, in cattle blood on the 0 , 28th, 56th, 84th day receiving control diet (without supplementation of selenium and copper), copper (40 mg/kg of DM), selenium ( $2 \mathrm{mg} / \mathrm{kg}$ of DM), or selenium (2 mg/kg of $\mathrm{DM}) /$ copper $(40 \mathrm{mg} / \mathrm{kg}$ of DM)

\begin{tabular}{lcccc}
\hline \multirow{2}{*}{ Treatments } & \multicolumn{4}{c}{ Cholesterol concentration $(\mathrm{mg} / \mathrm{dL})$ in blood at different times } \\
\cline { 2 - 5 } & 0 & 28th day & 56th day & 84th day \\
\hline Control $^{\mathrm{a}}$ & $103.07 \pm 11.9$ & $117.53 \pm 10.1$ & $122.29 \pm 9.5$ & $126.88 \pm 9.6$ \\
Copper $^{(\mathrm{Cu})}{ }^{\mathrm{b}}$ & $101.86 \pm 10.4$ & $107.08 \pm 8.4$ & $122.38 \pm 13.5$ & $107.07 \pm 5.3$ \\
Selenium $(\mathrm{Se})^{\mathrm{c}}$ & $112.68 \pm 5.9$ & $97.88 \pm 8.7$ & $127.55 \pm 14.7$ & $110.11 \pm 9.8$ \\
$\mathrm{Se} / \mathrm{Cu}^{\mathrm{d}}$ & $106.96 \pm 13.6$ & $103.5 \pm 5.8$ & $121.34 \pm 10.1$ & $113.65 \pm 7.9$ \\
\hline
\end{tabular}

${ }^{a}$ Control diet (without supplementation of copper and selenium).

${ }^{\mathrm{b}}$ Suplementation of selenium $\left(2 \mathrm{mg} / \mathrm{kg}\right.$ of DM). ${ }^{\mathrm{c}}$ Suplementation of copper $(40 \mathrm{mg} / \mathrm{kg}$ of DM).

${ }^{\mathrm{d}}$ Suplementation of selenium ( $2 \mathrm{mg} / \mathrm{kg}$ of DM) and copper (40 $\mathrm{mg} / \mathrm{kg}$ of DM).

There was no effect of the supplementation of copper, selenium or selenium and copper in serum cholesterol $(\mathrm{p}>0.05)$.

supplementation did not alter the profile of fatty acids in the meat or in its composition of saturated or unsaturated fatty acids. A lower proportion of linoleic and palmitic acid with the selenium/copper treatment in relation to the control was observed $(\mathrm{p}<0.05)$.

The composition of fatty acids in meat is the result of lipogenesis in adipose tissue and dietary lipids and subsequent ruminal biohydrogenation (Berchielli et al., 2006). Some authors found changes in the composition of fatty acids, reduction in saturated fatty acids and increase in unsaturated fatty acids with copper supplementation in the levels of the present study. Engle et al. (1999, 2000a) and Engle and Spears (2000) found an increase in C18:2 and C18:3 with supplementation of physiological levels of copper. The explanation of these authors was based on a depletion of ruminal biohydrogenation promoted by copper and consequently an increase in intestinal absorption of unsaturated fatty acids. Engle et al. (2000b) explained that the high reduction potential of copper in the rumen can reduce equivalents of reduction in the form of NADPH and $\mathrm{NADH}$, interfering in microbial biohydrogenation of unsaturated fatty acids.

In the present study, there was no change in the fatty acid profile with copper or selenium supplementation. Thus, there was no influence of copper on ruminal biohydrogenation. Engle at al. (2000c) studied the effect of copper supplementation and soybean oil on ruminal biohydrogenation and found an interaction between copper supplementation and soybean oil. The authors found a reduction in ruminal biohydrogenation only when copper was offered and an increase of biohydrogenation when copper and soybean oil were supplied together.

Soybeans were the source of lipids used in this study, present in extruded soybean. This may have been the reason why no effects were found in the fatty acid composition with copper, selenium and selenium/copper supplementation, since copper supplementation reduces biohydrogenation but supplementation combined with soybean oil seems to inhibit this effect.

The decrease in linoleic and palmitic acid with the selenium/copper treatment in relation to the control cannot be explained biologically and it was not observed in any work in the literature. This inconsistency may be partially explained by the difference in $\mathrm{Cu}$ levels or sources, diet fed and duration of supplementation.

\section{Blood and liver measurement}

Copper, selenium or selenium and copper supplementation had no effect on serum cholesterol on days 28,56 , or 84 after the start of the experimental period (p>0.05, Table 4). For muscular cholesterol, treatments with $40 \mathrm{mg} / \mathrm{kg}$ of copper and $2 \mathrm{mg} / \mathrm{kg}$ of selenium supplemented separately, showed lower muscular cholesterol concentration than the control treatment $(\mathrm{p}<0.05)$. However, there was no effect of the combined supplementation of these two minerals when compared to the control group $(p>0.05$, Figure 1).

Engle et al. (2000a) found no effect of copper supplementation on serum cholesterol levels up to the 56th day, however, these levels decreased on the 96th day. Thus, it is possible that the levels of total serum cholesterol had decreased after the 84th day of their study, since after 101

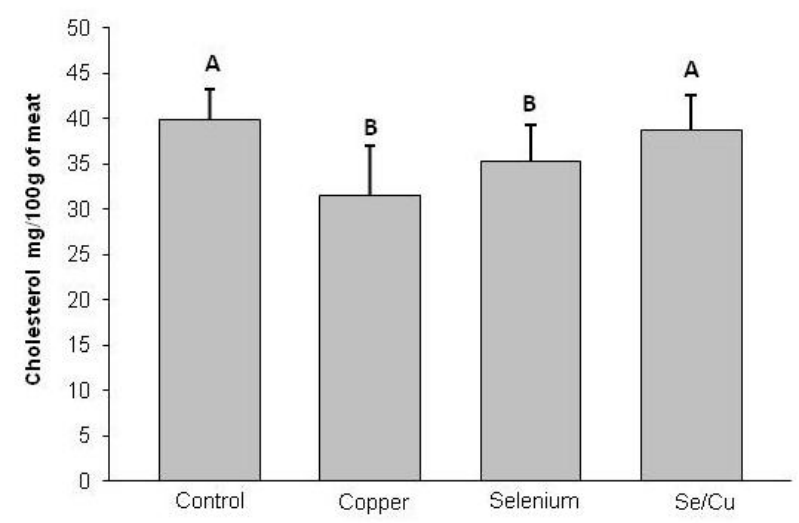

Figure 1. Concentration of cholesterol and standard deviations in mg per 100 grams of meat, in the Longissimus dorsi muscle of cattle receiving control diet (without supplementation of selenium and copper), copper (40 mg/kg of DM), selenium ( $2 \mathrm{mg} / \mathrm{kg}$ of $\mathrm{DM})$, or selenium (2 $\mathrm{mg} / \mathrm{kg}$ of DM)/copper (40 mg/kg of DM). 
days of supplementation all animals were slaughtered and a lower deposition of cholesterol in the LD muscle was observed in copper and selenium treatments compared to the control. This would explain the results obtained in our study, showing the non-influence of copper, selenium and selenium/copper supplementation in serum cholesterol, in the period and levels studied.

Furthermore, total cholesterol is largely composed by LDL, which has a long half-life. In other words, the effect of synthesis reduction could have occurred before the 84th day, but was not evidenced because of the long half-life of LDL. Some authors have shown a relationship between copper supplementation and the cholesterol metabolism in different animals. As in the present study, some authors found a decrease in deposition of cholesterol in LD with copper supplementation in ruminants, including Engle and Spears (2000), Engle et al. (2000a, c), and in non-ruminants such as described by Konjufca et al. (1997), Pesti and Bakalli (1996), Armstrong et al. (2001).

Kim et al. (1992) showed that copper deficiency causes hypercholesteromy because of the increase in hepatic GSH with an increase in HMG-CoA reductase activity, which is the main enzyme that regulates the synthesis of cholesterol. Figure 2, 3, and 4 show GSH and GSSG concentration and the relationship between GSH/GSSG in cattle livers in different treatments.

The selenium/copper treatment had lower concentrations of GSH, when compared with isolated selenium and copper treatments $(\mathrm{p}<0.05)$, however, selenium, copper and selenium/copper treatments did not differ from the control treatment. For GSSG, the selenium, copper and selenium/copper treatments showed higher values than the control $(\mathrm{p}<0.05)$. Therefore, the most accepted hypothesis is that the high concentration of copper in the liver indirectly regulates the biosynthesis of cholesterol by decreasing the reduced form of glutathione

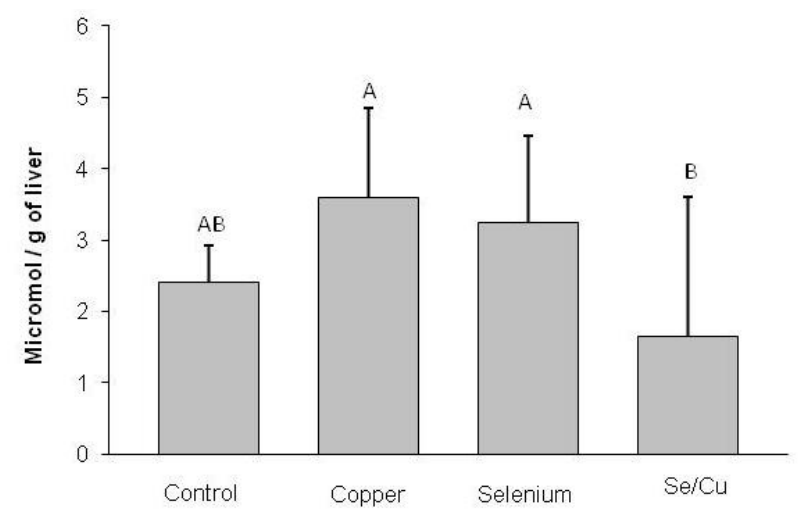

Figure 2. GSH and standard deviations, in $\mu \mathrm{mol}$ per gram of liver, of cattle receiving control diet (without supplementation of selenium and copper), copper (40 $\mathrm{mg} / \mathrm{kg}$ of $\mathrm{DM})$, selenium (2 $\mathrm{mg} / \mathrm{kg}$ of DM), or selenium (2 mg/kg of DM)/copper $(40 \mathrm{mg} / \mathrm{kg}$ of DM).

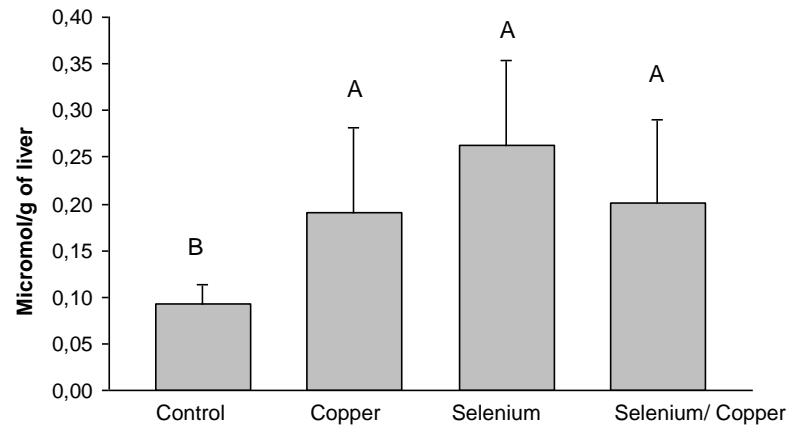

Figure 3. GSSG and standard deviations, in $\mu \mathrm{mol}$ per gram of liver, of cattle receiving control diet (without supplementation of selenium and copper), copper (40 $\mathrm{mg} / \mathrm{kg}$ of $\mathrm{DM})$, selenium (2 $\mathrm{mg} / \mathrm{kg}$ of DM), or selenium (2 mg/kg of DM)/copper (40 mg/kg of DM).

(GSH) and increasing the oxidized form (GSSG). The increase in the oxidized concentration (GSSG) found in this study for the selenium, copper and selenium/copper treatments, reduces the activity of the HMG-CoA enzyme (Gilbert cited by Engle and Spears, 2001). According to Armstrong et al. (2001) HMG-CoA reductase requires "thiols" as GSH for its activity and disulfides such as GSSG, which decreases the activity of this enzyme.

The literature shows no studies relating selenium supplementation and synthesis, or deposition of cholesterol in animals of any zootechnical interest, however, the change in glutathione metabolism justifies the results obtained. In the selenium/copper treatment, a decrease in deposition of cholesterol in the LD muscle was not observed. This result may have occurred due to an interaction between these two micro minerals, and a possible increase in the biosynthesis of glutathione by increasing selenium.

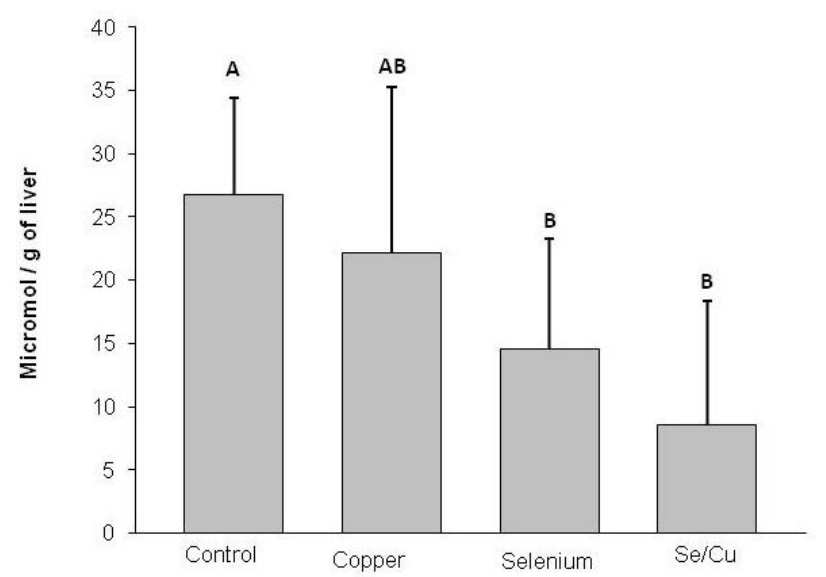

Figure 4. Relation between GSH and GSSG and standard deviations, in $\mu \mathrm{mol}$ per gram of liver, of cattle receiving control diet (without supplementation of selenium and copper), copper (40 $\mathrm{mg} / \mathrm{kg}$ of DM), selenium ( $2 \mathrm{mg} / \mathrm{kg}$ of DM), or selenium $(2 \mathrm{mg} / \mathrm{kg}$ of DM)/copper (40 mg/kg of DM). 


\section{CONCLUSIONS}

The results confirmed the hypothesis proposed that copper or selenium supplementation altered lipid metabolism on confined Brangus cattle. There was an increase in the concentration of the oxidized form (GSSG), for the selenium, copper and selenium/copper treatments. Selenium supplementation had an effect on the GSH/GSSG relationship.

Copper and selenium are essential for improving animal performance and feed efficiency in confined Brangus bulls.

\section{REFERENCES}

Armstrong, T. A., J. W. Spears, and T. E. Engle. 2001. Effect of pharmacological concentrations of dietary copper on lipid and cholesterol metabolism in pigs. Nutr. Res. 21:1299-1308.

AOAC. 1996. Official methods of analysis, 16th ed. Association of Official Analytical Chemists, Arlington, p. 1298.

Bakalli, R. I., G. M. Pesti, W. L. Ragland, and V. Konjufca. 1995. Dietary copper in excess of nutritional requirement reduces plasma and breast muscle cholesterol in chickens. Poult. Sci. 74:360-365.

Balevi, T. and B. Coskun. 2004. Effects of dietary copper on production and egg cholesterol content in laying hens. Br. Poult. Sci. 45:530-534.

Berchielli, T. T., A. Vaz Pires, and S. G. Oliveira. 2006. Nutrição de Ruminantes. Jaboticabal: Funep 1, 200-583.

Boila, R. J. 1987. Supplementary trace minerals for feedlot finishing of beef steers. Can. J. Anim. Sci. 67:765-774.

Cheng, J., C. Fan, W. Zhang, X. Zhu, X. Yan, R. Wang, and Z. Jia. 2008. Effects of dietary copper source and level on performance, carcass characteristics and lipid metabolism in lambs. Asian-Aust. J. Anim. Sci. 21:685-691.

Correa, L. B., M. A. Zanetti, G. R. Del Claro, M. P. Melo, A. F. Rosa, and A. Saran Netto. 2012. Effect of supplementation of two sources and two levels of copper on lipid metabolism in Nellore beef cattle. Meat Sci. 91:466-471.

Engle, T. E., J. W. Spears, and T. A. Armstrong. 1999. Performance and lipid and cholesterol metabolism in finishing steers fed vaying concentration of copper. J. Anim. Sci. 77:2446-2451.

Engle, T. E. and J. W. Spears. 2000. Dietary copper effects on lipid metabolism. performance and ruminal fermentation in finishing steers. J Anim Sci. 78:2452-2458.

Engle, T. E., J. W. Spears, and T. A. Armstrong. 2000a. Effects of dietary copper source and concentration on carcass characteristics and lipid and cholesterol metabolism in growing and finishing steers. J. Anim. Sci. 78:1053-1059.

Engle, T. E., J. W. Spears, and F. W. Edens. 2000b. Dietary copper effects on lipid metabolism and circulating catecholamine concentration in finising steers. J. Anim. Sci. 78:2737-2744.
Engle, T. E., J. W. Spears, and L. XI. 2000c. Effects of dietary soybean oil and dietary copper on ruminal and tissue lipid metabolism in finishing steers. J. Anim. Sci. 78: 2713-2721.

Engle, T. E. and J. W. Spears. 2001. Performance.carcass characteristics and lipid metabolism in growing and finishing Simmental steers fed vaying concentration of copper. J Anim Sci. 79:2920-2925.

Engle, T. E. and J. W. Spears. 2004. Effect of finisihing system (feedlot or pasture), hight oil maize, and copper on conjugated linoleic and other fatty acids in muscle of finishing steers. $\mathrm{J}$ Anim. Sci. 78:261-269.

Fettman, M. J. 1991. Comparative aspects of glutathione metabolism affecting individual susceptibility to oxidant injury. Comp. Cont. Educ. Pract. Vet. 13:1079-1091.

Holben, D. H. 1999. The diverse role of selenium within selenoproteins: A review. J. Am. Diet. Assoc. 99:836-843.

Kim, S., P. Y. Chao, and K. G. D. Allen. 1992. Inhibition of elevated hepatic glutathione abolishes copper deficiency cholesterolemia. FASEB J. 6:2467-2471.

Konjufca, V. H., G. M. Pesti, and L. I. Bakalli. 1997. Modulation of cholesterol levels in broiler meat by garlic and copper. Poult. Sci. 76:1264-1271.

Lawler, T. L., J. B. Taylor, and J. W. Finley. 2004. Effect of supranutritional and organically bond selenium on performance carcass characteristics, and selenium distribution in fishing beef steers. J. Anim. Sci. 82:1488-1493.

McDowell, L. R. 1992. Minerals in Animal and Human Nutrition. New York: Academic Press.

National Research Council. 2000. Nutrient requirements of cattle. Washington: National Academy Press, p. 232.

Olson, O. E., L. S. Palmer, and E. L. Cary. 1975. Modification of the official fluorometric method for selenium in plants. J. Assoc. Off. Anal. Chem. 58:117-121.

Perez, J. R. O., M. C. Bressan, and N. Bragagnolo. 2002. Efeito do peso ao abate de cordeiros Santa Inês e bergamácia sobre o perfil de ácidos graxos. colesterol e propriedades químicas. Ciênc. Tecnol. Aliment. 22:11-18.

Pesti, M. G. and R. L. Bakalli. 1996. Studies on feeding of cupric sulfate pentahydrate and cupric citrate to broiler chickens. Poult. Sci. 75:1086-1091.

Saldanha, T., M. R. Mazali, and M. Bragagnolo. 2004. Avaliação comparativa entre dois métodos para determinação do colesterol em carnes e leite. Ciênc. Tecnol. Aliment. 24:109113.

SAS. 2004. SAS start guide. Version 6.03. Cary, NC: SAS Institute Inc., $1028 \mathrm{p}$.

Skrivan, M., S. Sevcikova, and E. Tumova. 2002. Effect of copper sulphate supplementation on performance of broiler chickens, cholesterol content and fatty acid profile of meat. Czech J. Anim. Sci. 47:275-280.

Zhang, W., R. L. Wang, X. P. Zhu, O. K. David, C. W. Yue, and Z. H. Jia. 2007. Effect of dietary copper on ruminal fermentation, nutrient digestibility and fibre characteristics in Chashmere goats. Asian-Aust. J. Anim. Sci. 20:1843-1848. 